\title{
Wing Configuration Impact on Design Optimums for a Subsonic Passenger Transport
}

\author{
Douglas P. Wells ${ }^{1}$ \\ NASA Langley Research Center, Hampton, VA, 23681
}

This study sought to compare four aircraft wing configurations at a conceptual level using a multi-disciplinary optimization (MDO) process. The MDO framework used was created by Georgia Institute of Technology and Virginia Polytechnic Institute and State University. They created a multi-disciplinary design and optimization environment that could capture the unique features of the truss-braced wing (TBW) configuration. The four wing configurations selected for the study were a low wing cantilever installation, a high wing cantilever, a strut-braced wing, and a single jury TBW. The mission that was used for this study was a 160 passenger transport aircraft with a design range of 2,875 nautical miles at the design payload, flown at a cruise Mach number of 0.78 . This paper includes discussion and optimization results for multiple design objectives. Five design objectives were chosen to illustrate the impact of selected objective on the optimization result: minimum takeoff gross weight (TOGW), minimum operating empty weight, minimum block fuel weight, maximum start of cruise lift-to-drag ratio, and minimum start of cruise drag coefficient. The results show that the design objective selected will impact the characteristics of the optimized aircraft. Although minimum life cycle cost was not one of the objectives, TOGW is often used as a proxy for life cycle cost. The low wing cantilever had the lowest TOGW followed by the strut-braced wing.

\section{Nomenclature}

$\begin{array}{ll}A R & =\text { aircraft wing aspect ratio } \\ B F W & =\text { block fuel weight } \\ C_{D} & =\text { total aircraft 3D drag coefficient } \\ C_{L} & =\text { total aircraft 3D lift coefficient } \\ F L O P S & =\text { Flight Optimization System } \\ L / D & =\text { lift-to-drag ratio } \\ M D O & =\text { Multi-Disciplinary Optimization } \\ N A S A & =\text { National Aeronautics and Space Administration } \\ O E W & =\text { operating empty weight } \\ S B W & =\text { strut-braced wing } \\ S F C & =\text { specific fuel consumption } \\ T B W & =\text { truss-braced wing } \\ T O G W & =\text { takeoff gross weight } \\ W / S & =\text { aircraft wing loading }\end{array}$

\footnotetext{
${ }^{1}$ Aerospace Engineer, Aeronautics Systems Analysis Branch, Mail Stop 442, AIAA Member.
} 


\section{Introduction}

$\mathrm{T}$ HE truss-braced wing (TBW) configuration has been the subject of numerous research studies over the last forty years. ${ }^{1}$ One of the first implementations on a passenger transport was in the 1950's. The French aircraft manufacturer Hurel-Dubois used the truss concept to brace their high aspect ratio (AR) wing on the HD-31 prototype in 1953. The HD-31 was a 36 passenger transport with a 148 foot span, featuring high-lift flaps and lifting struts. ${ }^{2}$ It had an aspect ratio of 20.2. Hurel-Dubois designed high aspect ratio wings for aircraft to achieve lower induced drag. They also believed that using lift-struts to achieve high aspect ratio wings would not increase the airframe weight. ${ }^{3}$ They claimed to have overcome other commonly accepted high AR design objections of the time, including: difficult flight and maneuverability characteristics, torsion problems that lead to aileron ineffectiveness and wing flutter, limited center of gravity travel from the short chord wing, and de-icing problems from a long leading edge, all while maintaining a high payload fraction and low cost. Air France ordered 24 of the more powerful HD-32, but it is not known why the order was not fulfilled or why the aircraft wasn't widely adopted. ${ }^{4}$ Figure 1 shows a picture of the HD-31 in flight.

Dr. Werner Pfenninger introduced a TBW design in 1975 to reduce structural weight and gain several aerodynamic benefits such as higher lift-to-drag ratio (L/D) and natural laminar flow. ${ }^{6}$ Figure 2 shows a drawing of Dr. Pfenninger's TBW. In order to increase the amount of laminar flow, Pfenninger used a structural truss on the main wing to decrease the chord length. The structural concept was necessary to support the high aspect ratio wing. The TBW became an interesting configuration for research since increasing $\mathrm{L} / \mathrm{D}$ and laminar flow have always been popular pursuits.

NASA is interested in advanced aircraft configurations that will help achieve the agency's environmental goals. The truss-braced wing is one configuration for which research has continued. NASA's involvement in the TBW has produced conference papers, ${ }^{7-15}$ journal articles, ${ }^{16-21}$ and college degree theses ${ }^{22-28}$ that show benefits of the truss configuration. The biggest questions that resulted from this research were: how much laminar flow is possible and will the wing or strut flutter? NASA contracted with Boeing to study the

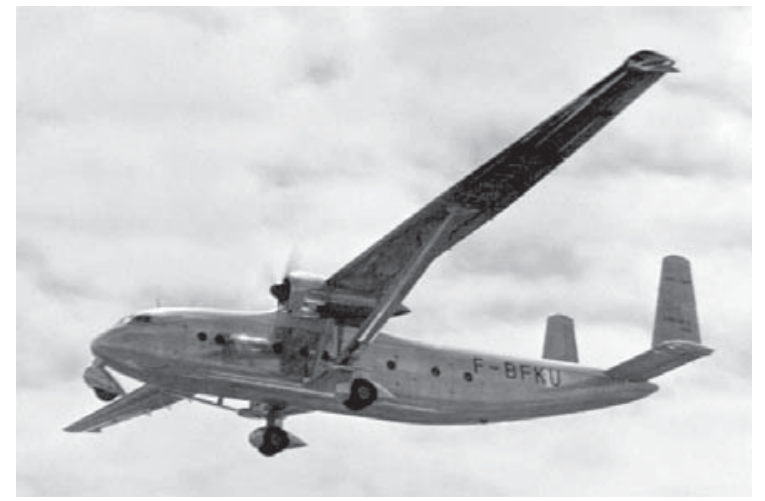

Figure 1: Hurel Dubois HD-31 Prototype. ${ }^{5}$

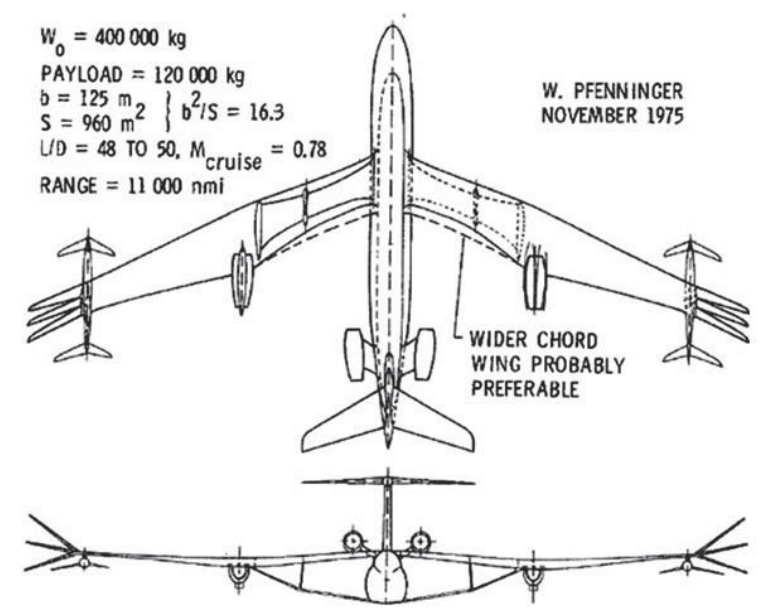

Figure 2: Dr. Werner Pfenninger's 1975 TBW. $^{6}$ biggest risk areas for the TBW. A two-dimensional wind tunnel test of natural laminar flow airfoils was completed in 2012 and a wind tunnel test is planned to test the flutter characteristics and limits of the Boeing designed TBW configuration in 2014. The results of the wind tunnel tests will be included in the final report of the contract, which is expected to be released to the public in 2014 or 2015.

Most of the studies referenced above investigated truss-braced wing and strut-braced wing aircraft. The studies did not include a high wing cantilever as an intermediate aircraft to help assess the true benefit of a strut-braced or truss-braced wing. This study sought to compare four wing configurations using the same multi-disciplinary optimization (MDO) method to allow for comparisons. The four wing configurations selected were a low wing cantilever installation, a high wing cantilever, a strut-braced wing (SBW), and a single jury TBW for a 160 passenger transport aircraft.

\section{Problem Statement}

This study focuses on a transport aircraft with a range of 2,875 nautical miles carrying 160 passengers. This mission is similar to that of the Boeing 737-800. The mission profile includes takeoff at sea-level, climb to optimum altitude, cruise at Mach 0.78, descent, and landing. Additional fuel for a reserve mission is also included. The 
reserve mission consists of a 200 nautical mile diversion, a 30 minute loiter, and an additional five percent of the mission fuel.

MDO is used to optimize the aircraft design for each wing configuration to provide a more consistent basis for comparison. The optimization problem can be described mathematically as a search to minimize or maximize a particular design objective using a given set of design variables. Design constraints are used to bound the design space or limit the designs to feasible or useful products. This study includes optimization results using different design objectives. There are some common misconceptions concerning the appropriate wing design objectives. For example, it is often assumed that the highest $\mathrm{L} / \mathrm{D}$ design of an aircraft is also the design that will have the lowest drag, which is not necessarily the case. Below is a description of the design objectives, variables and constraints.

\section{A. Design Objectives}

The design objectives drive the MDO. Given enough freedom in the constraints and design variables, completely different aircraft can result from an optimization run with a different design objective. Five design objectives were chosen in the study to illustrate this point: minimum Takeoff Gross Weight (TOGW), minimum Block Fuel Weight (BFW), minimum Operating Empty Weight (OEW), maximum start of cruise Lift-to-Drag Ratio (L/D), and minimum start of cruise drag coefficient $\left(C_{D}\right)$.

\section{B. Design Variables}

The design variables used in this study are limited to the wing geometry parameters, engine spanwise location, and engine thrust. Table 1 shows a list of the design variables used in the MDO for each wing configuration. This study used wide ranges for the design variable inputs to insure the designs were not artificially constrained. However, this does enable the optimizer to select designs that are somewhat unrealistic and would not be manufactured.

Table 1: Design Variable Matrix.

\begin{tabular}{|c|c|c|c|c|c|}
\hline & Units & $\begin{array}{l}\text { Low Wing } \\
\text { Cantilever }\end{array}$ & $\begin{array}{l}\text { High Wing } \\
\text { Cantilever }\end{array}$ & $\begin{array}{l}\text { Strut-Braced } \\
\text { Wing }\end{array}$ & $\begin{array}{l}\text { Truss-Braced } \\
\text { Wing }\end{array}$ \\
\hline \multicolumn{6}{|l|}{ Wing Variables } \\
\hline Aspect Ratio & & $4-20$ & $4-20$ & $4-20$ & $4-20$ \\
\hline Area & $\mathrm{ft}^{2}$ & $500-3000$ & $500-3000$ & $500-3000$ & $500-3000$ \\
\hline Taper Ratio & & $0.001-1$ & $0.001-1$ & $0.001-1$ & $0.001-1$ \\
\hline Sweep & deg. & $0-35$ & $0-35$ & $0-35$ & $0-35$ \\
\hline Thickness-to-Chord Ratio & & $0.05-0.25$ & $0.05-0.25$ & $0.05-0.25$ & $0.05-0.25$ \\
\hline $\begin{array}{r}\text { Wing Planform Break Location (as } \\
\text { a percent of semi-span) }\end{array}$ & $\%$ & $10-70$ & $10-70$ & $10-70$ & $10-70$ \\
\hline \multicolumn{6}{|l|}{ Strut Variables } \\
\hline Thickness-to-Chord Ratio & & & & $0.07-0.2$ & $0.07-0.2$ \\
\hline $\begin{array}{r}\text { Chord Length (as a percent of wing } \\
\text { chord at attachment location) }\end{array}$ & $\%$ & & & $10-90$ & $10-90$ \\
\hline \multicolumn{6}{|l|}{ Jury Variables } \\
\hline Thickness-to-Chord Ratio & & & & & $0.07-0.2$ \\
\hline $\begin{array}{r}\text { Chord Length (as a percent of strut } \\
\text { chord at attachment location) }\end{array}$ & $\%$ & & & & $10-90$ \\
\hline $\begin{array}{r}\text { Strut Attachment Location (as a } \\
\text { percent of strut span) }\end{array}$ & $\%$ & & & & $10-90$ \\
\hline $\begin{array}{r}\text { Wing Attachment Location (as a } \\
\text { percent of wing semi-span) }\end{array}$ & $\%$ & & & & $10-90$ \\
\hline \multicolumn{6}{|l|}{ Propulsion Variables } \\
\hline Thrust & $\mathrm{lb}$ & $\begin{array}{c}15,000- \\
38,000\end{array}$ & $\begin{array}{l}15,000- \\
38,000\end{array}$ & $\begin{array}{c}15,000- \\
38,000\end{array}$ & $\begin{array}{l}15,000- \\
38,000\end{array}$ \\
\hline Engine Spanwise Location & $\mathrm{ft}$ & $6-35$ & $6-35$ & $6-35$ & $6-35$ \\
\hline
\end{tabular}




\section{Design Constraints}

The design constraints bound the problem. They were based on a baseline aircraft that is similar to the Boeing 737-800. The constraints are used in this study to ensure adequeate aircraft performance and guarantee the resulting aircraft are at least capable of the performance of the baseline. The design constraints are as follows:

1) Range: The range of the aircraft must be greater than or equal to $2,875 \mathrm{~nm}$ with fuel remaining to complete the reserve mission.

2) Approach Speed: The approach speed must not exceed 134 kts This constraint is based on results of the baseline analysis using the same environment.

3) Takeoff Field Length: The takeoff field length must not exceed 10,200 ft.

4) Landing Field Length: The landing field length must not exceed 8,100 ft.

5) Missed Approach: The excess thrust available during a one-engine-out missed approach must be greater than zero.

6) Second Segment Climb: The excess thrust available during a one-engine-out second segment climb must be greater than zero.

7) Excess Fuel Capacity: The wing must have enough fuel volume to carry the required mission fuel plus reserves. The excess fuel capacity must be greater than zero.

\section{Assumptions}

This study sought to characterize a large design space. In order keep the problem manageable and not lose any large factors, several assumptions were made and carefully considered. The design variables were limited to the wing geometry parameters, engine spanwise location, and engine thrust. Consequently, the fuselage and tail geometry were essentially fixed within each configuration. The fuselage was lengthened with the high wing configurations to account for additional emergency exits and slides because of the removal of over-wing exits. A tail sizing routine was used in the MDO to size the horizontal and vertical tails based on the fuselage and wing geometry. ${ }^{29}$ Late 1990 's technology levels were assumed with fully turbulent skin friction drag. In other words, no technology factors were used during this study. This enables the benefits of the wing configurations alone to be shown without additional benefits from advanced technologies. This study also assumed a fixed mission for all of the wing configurations. The mission is similar to the capabilities of an existing 160 passenger transport aircraft. A rubberized engine model with a reference sea-level static thrust of about 26,400 pounds was used across all of the wing configurations. The rubberized engine is a model with characteristics for a specific reference thrust that are scaled to model larger and smaller engines.

\section{E. Optimization Methodology}

A combination of genetic algorithm and gradient algorithm were used in this study for the optimization method. First, the genetic algorithm was used to find a global optimum. Next, the gradient method was started at that global optimum. This method was used consistently for all of the 20 optimization cases.

\section{Multi-Disciplinary Optimization Framework}

The tools and methods used for any analysis have a large impact on the outcome. The analysis framework used for this study was created by Georgia Institute of Technology (Georgia Tech) and Virginia Polytechnic Institute and State University (Virginia Tech) in Phoenix Integration's ModelCenter ${ }^{\circledR}{ }^{30}$ They created a multi-disciplinary design and optimization (MDO) environment that could capture the unique features of the TBW. ${ }^{12}$ The environment uses multi-disciplinary analysis modules including aerodynamics, structures, weights, propulsion, geometry, and performance. The structures module did not include wing flutter penalties. The current MDO framework does not capture the detailed coupling and interactions among different disciplines such as aerodynamics and structures to save computational time. There was a focus on low computational time to enable analysis in minutes rather than hours or weeks.

\section{Results}

The results of the MDO study are split into three major sections. First, discussion of the baseline aircraft will be presented, followed by differences between design objectives. Finally, the comparison of the optimized wing configurations will be shown. 


\section{A. Baseline Aircraft}

A baseline model was created for each of the wing configurations to be used as a starting point for the optimization. The design variables were not changed between the aircraft to isolate the changes due to the wing configuration. The fuselage did change from the low wing cantilever to the high wing cantilever configuration. The tail for the high wing cantilever configuration was also changed to a t-tail. The high wing, SBW, and TBW all have a t-tail configuration that was sized with the tail sizing routine mentioned above. A strut was added to the high wing cantilever to reach the strut-braced wing configuration. One jury was added to the strut-braced wing to reach the truss-braced wing configuration. The low wing cantilever baseline was modeled based on an existing production aircraft. However, the high wing cantilever, strut-braced wing, and truss-braced wing configurations are modifications from the low wing cantilever and are likely not representative of production aircraft for their respective configurations. Table 2 shows the analysis results of each wing configuration baseline.

Table 2: Baseline Wing Configurations Analysis Results.

\begin{tabular}{|c|c|c|c|c|c|}
\hline & Units & $\begin{array}{l}\text { Low Wing } \\
\text { Cantilever }\end{array}$ & $\begin{array}{l}\text { High Wing } \\
\text { Cantilever }\end{array}$ & $\begin{array}{l}\text { Strut-Braced } \\
\text { Wing }\end{array}$ & $\begin{array}{c}\text { Truss-Braced } \\
\text { Wing }\end{array}$ \\
\hline \multicolumn{6}{|l|}{ Mission Parameters } \\
\hline TOGW & $\mathrm{lb}$ & 173,800 & 174,900 & 175,200 & 177,200 \\
\hline OEW & $\mathrm{lb}$ & 91,800 & 92,900 & 92,100 & 93,100 \\
\hline Wing Weight & $\mathrm{lb}$ & 19,300 & 19,200 & 18,500 & 19,300 \\
\hline Payload & $\mathrm{lb}$ & 37,760 & 37,760 & 37,760 & 37,760 \\
\hline Number of Passengers & & 160 & 160 & 160 & 160 \\
\hline Range & $\mathrm{nm}$ & 2,875 & 2,875 & 2,875 & 2,875 \\
\hline Total Fuel & $\mathrm{lb}$ & 44,200 & 44,200 & 45,300 & 46,400 \\
\hline Block Fuel & $\mathrm{lb}$ & 36,200 & 36,300 & 37,200 & 38,200 \\
\hline Economic Range & $\mathrm{nm}$ & 900 & 900 & 900 & 900 \\
\hline Economic Mission Blk Fuel & $\mathrm{lb}$ & 12,000 & 12,000 & 12,200 & 12,500 \\
\hline \multicolumn{6}{|l|}{ Aircraft Parameters } \\
\hline Wing Area & $\mathrm{ft}^{2}$ & 1,340 & 1,340 & 1,340 & 1,340 \\
\hline Wing Span & $\mathrm{ft}$ & 112 & 112 & 112 & 112 \\
\hline AR & & 9.4 & 9.4 & 9.4 & 9.4 \\
\hline Wing Loading, W/S & $\mathrm{lb} / \mathrm{ft}^{2}$ & 130 & 130 & 131 & 132 \\
\hline Cruise Mach & & 0.78 & 0.78 & 0.78 & 0.78 \\
\hline Start of Cruise L/D & & 17.7 & 17.9 & 17.4 & 17.1 \\
\hline Start of Cruise $C_{L}$ & & 0.47 & 0.50 & 0.50 & 0.50 \\
\hline Start of Cruise $C_{D}$ & & 0.0268 & 0.0280 & 0.0288 & 0.0293 \\
\hline Start of Cruise Altitude & $\mathrm{ft}$ & 30,100 & 31,100 & 31,100 & 30,900 \\
\hline Thrust per Engine & $\mathrm{lb}$ & 26,400 & 26,400 & 26,400 & 26,400 \\
\hline Start of Cruise SFC & $1 / \mathrm{hr}$ & 0.619 & 0.618 & 0.619 & 0.619 \\
\hline \multicolumn{6}{|l|}{ Constraints } \\
\hline Range & $\mathrm{nm}$ & 2,875 & 2,875 & 2,875 & 2,875 \\
\hline Approach Speed & kts & 133 & 134 & 134 & 135 \\
\hline Takeoff Field Length & $\mathrm{ft}$ & 8,760 & 8,880 & 8,910 & 9,140 \\
\hline Landing Field Length & $\mathrm{ft}$ & 7,830 & 7,870 & 7,880 & 7,950 \\
\hline Missed Approach & $\mathrm{lb}$ & 1,220 & 1,100 & 1,070 & 840 \\
\hline Second Segment Climb & $\mathrm{lb}$ & 6,690 & 6,600 & 6,590 & 6,450 \\
\hline
\end{tabular}

The low wing has the lowest block fuel and start of cruise drag coefficicent. The takeoff gross weight increases slightly when going from the low wing to the high wing. The L/D also increases as does the block fuel and operating empty weight. The high wing has the highest L/D. Takeoff gross weight again increases slightly going from the high wing to the strut-braced wing. In this case, the L/D and operating empty weight decrease while the block fuel increases. Takeoff gross weight increases going from the strut-braced wing to the truss-braced wing, to the highest TOGW for all of the baselines. The truss-braced wing has the lowest L/D. The truss-braced wing baseline has the highest operating empty weight and block fuel. Figure 3 shows Vehicle Sketch Pad models of the baseline aircraft. 


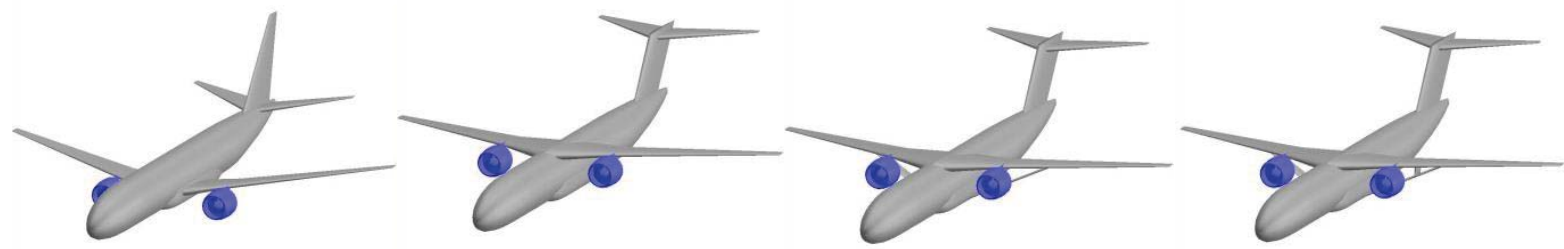

Figure 3: Vehicle Sketch Pad models of the four baseline aircraft: low wing cantilever, high wing cantilever, strut-braced wing, and truss-braced wing (from left to right).

\section{B. Design Objectives}

The selection of the design objective determines the outcome of the MDO. Different design objectives will result in different optimum aircraft if enough design variables are used with adequate ranges. For example, the highest $\mathrm{L} / \mathrm{D}$ design is not necessarily the same as the lowest drag. Table 3 shows the low wing cantilever configuration results for the TOGW, OEW, BFW, L/D, and Drag Coefficient design objectives. The active constraints are highlighted in red font.

Table 3: Low Wing Cantilever Aircraft MDO Design Objective Results.

\begin{tabular}{|l|c|r|r|r|r|r|}
\hline \multicolumn{1}{|c|}{ Mission Parameters } & Units & TOGW & OEW & BFW & L/D & $C_{\mathrm{D}}$ \\
\hline TOGW & $\mathrm{lb}$ & 154,100 & 158,000 & 166,300 & 189,500 & 186,500 \\
\hline OEW & $\mathrm{lb}$ & 86,600 & 84,200 & 100,000 & 121,500 & 107,000 \\
\hline Payload & $\mathrm{lb}$ & 37,760 & 37,760 & 37,760 & 37,760 & 37,760 \\
\hline Number of Passengers & & 160 & 160 & 160 & 160 & 160 \\
\hline Range & $\mathrm{nm}$ & 2,875 & 2,875 & 2,875 & 2,875 & 2,875 \\
\hline Total Fuel & $\mathrm{lb}$ & 29,800 & 36,000 & 28,500 & 30,200 & 41,800 \\
\hline Block Fuel & $\mathrm{lb}$ & 24,200 & 29,500 & 22,900 & 24,100 & 35,300 \\
\hline Economic Range & $\mathrm{nm}$ & 900 & 900 & 900 & 900 & 900 \\
\hline Economic Mission Blk Fuel & $\mathrm{lb}$ & 8,500 & 9,920 & 8,360 & 9,010 & 11,200 \\
\hline Aircraft Parameters & & & & & & \\
\hline Wing Area & $\mathrm{ft}{ }^{2}$ & 1,350 & 1,280 & 1,850 & 1,960 & 2,410 \\
\hline Wing Span & $\mathrm{ft}$ & 133 & 114 & 169 & 198 & 208 \\
\hline AR & & 13.2 & 10.2 & 15.4 & 20.0 & 18.1 \\
\hline Wing Loading, W/S & $\mathrm{lb} / \mathrm{ft}{ }^{2}$ & 115 & 123 & 90 & 97 & 78 \\
\hline Cruise Mach & & 0.78 & 0.78 & 0.78 & 0.78 & 0.78 \\
\hline Start of Cruise L/D & & 25.0 & 20.2 & 29.7 & 32.9 & 19.4 \\
\hline Start of Cruise C & & 0.53 & 0.50 & 0.53 & 0.59 & 0.26 \\
\hline Start of Cruise C $\mathrm{D}_{\mathrm{D}}$ & & 0.0211 & 0.0247 & 0.0180 & 0.0179 & 0.0136 \\
\hline Start of Cruise Altitude & $\mathrm{ft}$ & 35,000 & 32,300 & 40,400 & 40,900 & 28,500 \\
\hline Thrust per Engine & $\mathrm{lb}$ & 19,600 & 22,200 & 19,800 & 23,000 & 17,300 \\
\hline Start of Cruise SFC & $1 / \mathrm{hr}$ & 0.612 & 0.617 & 0.616 & 0.617 & 0.633 \\
\hline Constraints & & & & & & \\
\hline Range & $\mathrm{nm}$ & 2,875 & 2,875 & 2,875 & 2,875 & 2,875 \\
\hline Approach Speed & $\mathrm{kts}$ & 126 & 130 & 111 & 115 & 104 \\
\hline Takeoff Field Length & $\mathrm{ft}$ & 9,140 & 9,120 & 7,240 & 7,470 & 7,960 \\
\hline Landing Field Length & $\mathrm{ft}$ & 7,210 & 7,540 & 6,210 & 6,580 & 5,740 \\
\hline Missed Approach & $\mathrm{lb}$ & 62 & 38 & 1,650 & 3,290 & 14 \\
\hline Second Segment Climb & $\mathrm{lb}$ & 4,080 & 5,100 & 4,110 & 5,170 & 1,430 \\
\hline & & & & & & \\
\hline
\end{tabular}

The optimized aircraft all have a maxiumum range of 2,875 nautical miles. Thus the range was an active constraint for all of the designs. The optimum TOGW, OEW, and $\mathrm{C}_{\mathrm{D}}$ are also very close to the Missed approach constraint. The lowest $C_{D}$ design burns the most fuel. It has a larger wing: more wing area, longer span, and higher aspect ratio 
making its lift coefficient significantly lower than the other designs. It is also interesting to note that with the exception of the low wing configuration, the minimum $C_{D}$ designs have the largest tails due to the large wing areas. The maximum lift-to-drag ratio design has the highest takeoff gross weight, the second largest wing, and the largest engine. Of the three weight based design objectives, the minimum block fuel design has the largest wing. The minimum operating empty weight design has the smallest wing. The minimum takeoff gross weight design is more balanced in that its $\mathrm{OEW}, \mathrm{BFW}, \mathrm{L} / \mathrm{D}$, and $\mathrm{C}_{\mathrm{D}}$ are in the middle of these five designs. It is also clear that the maximum $\mathrm{L} / \mathrm{D}$ design does not have the lowest $\mathrm{C}_{\mathrm{D}}$. That is why using a metric like lowest $\mathrm{L} / \mathrm{D}$ can be deceiving.

This study produced 20 optimized aircraft. One way to visualize the results of each configuration is to compare them using the five top level design objective parameters. Figure 4 shows the results in five separate bar charts.

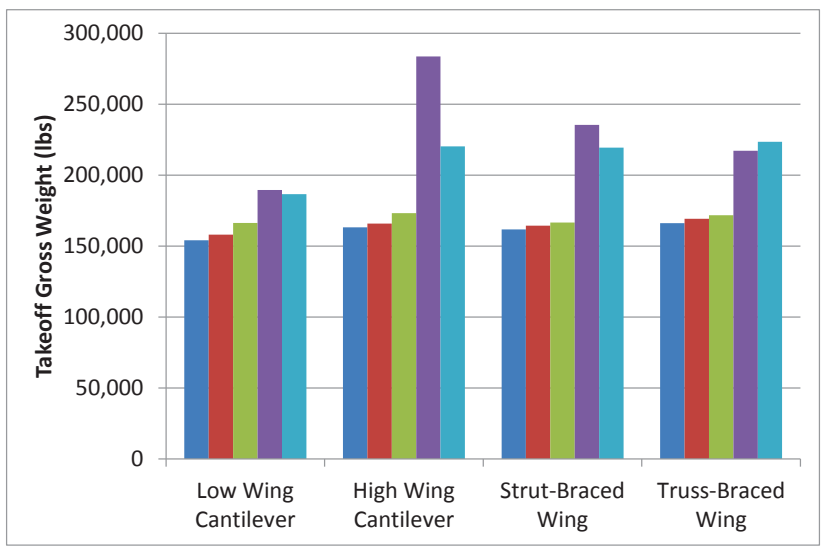

a) Optimization Result Takeoff Gross Weights

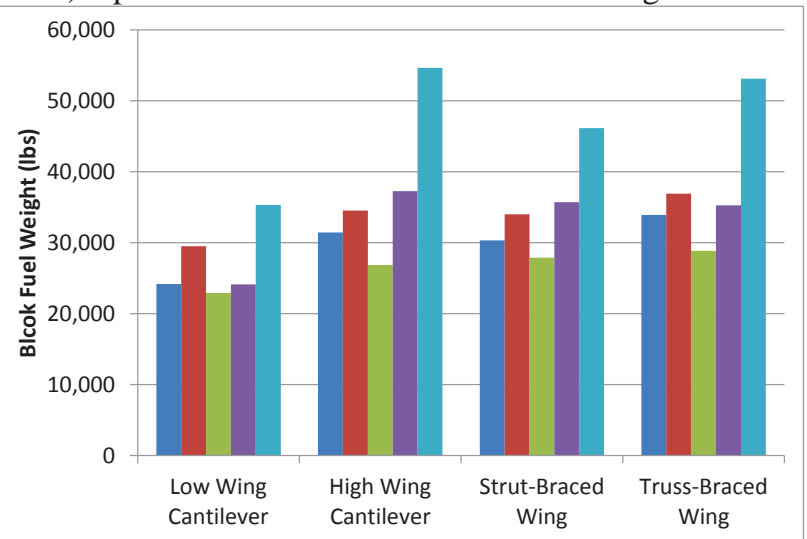

c) Optimization Result Block Fuel Weights

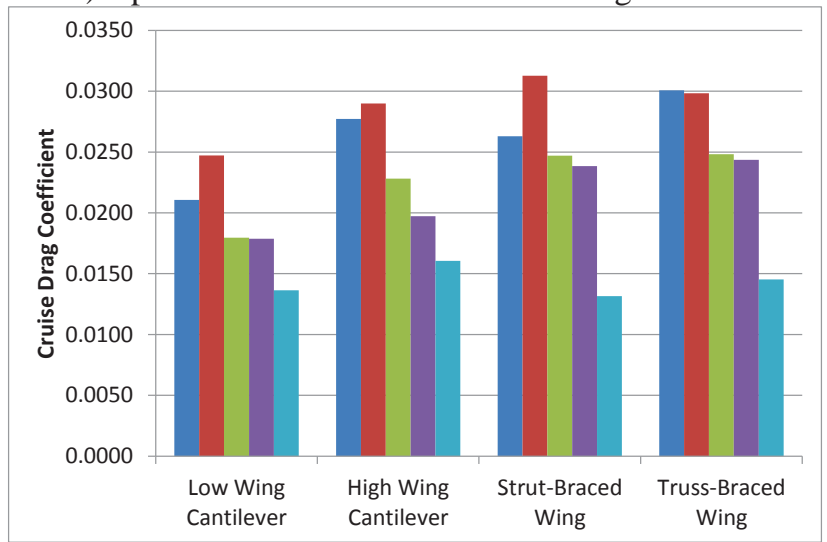

e) Optimization Result Cruise Drag Coefficients

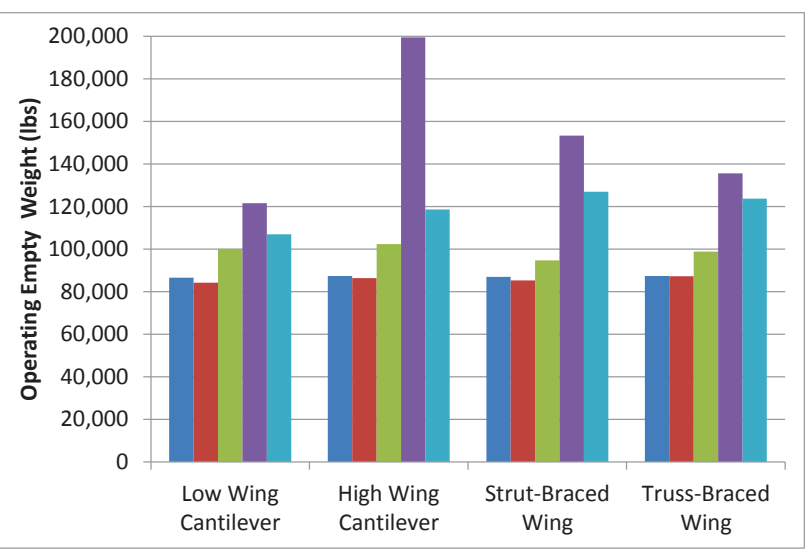

b) Optimization Result Operating Empty Weights

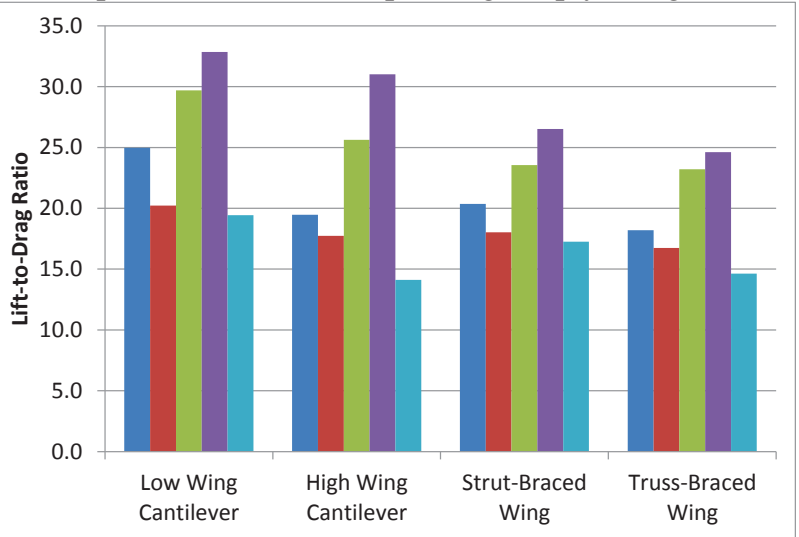

d) Optimization Result Lift-to-Drag Ratios
Min. Takeoff Gross Weight

Min. Operating Empty Weight

Min. Block Fuel Weight

Max. Lift-to-Drag Ratio

Min. Drag Coefficient

Figure 4: Optimization Results Comparison Across the Design Ojective Parameters. 
Figure 4a shows that the aerodynamically optimized designs have the highest takeoff gross weights for each wing configuration. Similar results are shown in Fig. 4b. There is also a trend that the lowest block fuel designs have higher OEW than the minimum TOGW and OEW designs. Figure 4c compares the block fuel. The minimum $\mathrm{C}_{\mathrm{D}}$ designs for each configuration gave the highest block fuel while the minimum takeoff gross weight designs gave the second best block fuel. Figure 4d compares the lift-to-drag ratios. The minimum block fuel designs have the second best $\mathrm{L} / \mathrm{D}$ and the minimum $\mathrm{C}_{\mathrm{D}}$ designs have the lowest L/D. Figure 4e shows the drag coefficients. The weight optimized designs, minimum TOGW, OEW, and BFW have the highest $\mathrm{C}_{\mathrm{D}}$.

The low wing configuration achieved the lowest TOGW, BFW, and highest L/D while the strut-braced wing configuration achieved the lowest OEW and $\mathrm{C}_{\mathrm{D}}$. It is clear that maximizing $\mathrm{L} / \mathrm{D}$ will increase the aircraft's weight. This is important because when total aircraft efficiency is measured in $\mathrm{L} / \mathrm{D}$ it can be misleading.

\section{Optimized Wing Configurations}

Takeoff gross weight is often used as a measurable quantity to indicate life cycle cost of an aircraft. This is one reason that takeoff gross weight is commonly chosen as the objective function when designing conceptual aircraft. This section will focus on comparing the four wing configurations that were optimized using the minimum takeoff gross weight objective function. The process for this study was to start with the low wing configuration, move the wing location to a high wing, add a strut, then add a jury. This section will step through the progression and discuss the results.

The first step of the study was to optimize the baseline aircraft. Table 4 contains the top level aircraft parameters for the low wing cantilever baseline and TOGW optimized aircraft. The TOGW optimized aircraft has almost 20,000 pounds less takeoff gross weight. Most likely, there were other design constraints and requirements for the existing aircraft modeled as the baseline that were not captured in the optimization process used for this study. The biggest geometry change is the increase in aspect ratio in the optimized design, because the wing weight methods don't sufficiently model the weight penality of increased aspect ratio. The other changes in the wing are the wing planform break location moves outboard and the inboard taper ratio increases. The geometry changes resulted in increased L/D, lift coefficient, and a decreased drag coefficient. Thrust required per engine also decreases with the improved aerodynamic parameters and decreased weight.

Table 4: Low Wing Cantilever Baseline and TOGW Optimized Aircraft.

\begin{tabular}{|c|c|c|c|c|c|c|c|}
\hline & Unit & Baseline & TOGW & & Units & Baseline & TOGW \\
\hline Mission Parameters & & & & Constraints & & & \\
\hline TOGW & $\mathrm{lb}$ & 173,800 & 154,100 & Range & $\mathrm{nm}$ & 2,875 & 2,875 \\
\hline OEW & $\mathrm{lb}$ & 91,800 & 86,600 & Approach Speed & kts & 133 & 126 \\
\hline Wing Weight & $\mathrm{lb}$ & 19,300 & 19,500 & Takeoff Field Length & $\mathrm{ft}$ & 8,760 & 9,140 \\
\hline Payload & $\mathrm{lb}$ & 37,760 & 37,760 & Landing Field Length & $\mathrm{ft}$ & 7,830 & 7,210 \\
\hline Number of Passengers & & 160 & 160 & Missed Approach & $\mathrm{lb}$ & 1,220 & 62 \\
\hline Range & $\mathrm{nm}$ & 2,875 & 2,875 & Second Segment Climb & $\mathrm{lb}$ & 6,690 & 4,080 \\
\hline Total Fuel & $\mathrm{lb}$ & 44,200 & 29,800 & & & & \\
\hline Block Fuel & $\mathrm{lb}$ & 36,200 & 24,200 & & & & \\
\hline Economic Range & $\mathrm{nm}$ & 900 & 900 & & & & \\
\hline $\begin{array}{l}\text { Economic Mission } \text { Blk } \\
\text { Fuel }\end{array}$ & $\mathrm{lb}$ & 12,000 & 8,500 & & & & \\
\hline \multicolumn{4}{|l|}{ Aircraft Parameters } & & & & \\
\hline Wing Area & $\mathrm{ft}^{2}$ & 1,340 & 1,350 & & & & \\
\hline Wing Span & $\mathrm{ft}$ & 112 & 133 & & & & \\
\hline AR & & 9.4 & 13.2 & & & & \\
\hline Wing Loading, W/S & $\mathrm{lb} / \mathrm{ft}^{2}$ & 130 & 115 & & & & \\
\hline Cruise Mach & & 0.78 & 0.78 & & & & \\
\hline Start of Cruise L/D & & 17.7 & 25.0 & & & & \\
\hline Start of Cruise $C_{L}$ & & 0.47 & 0.53 & & & & \\
\hline Start of Cruise $C_{D}$ & & 0.0268 & 0.0211 & & & & \\
\hline Start of Cruise Altitude & $\mathrm{ft}$ & 30,100 & 35,000 & & & & \\
\hline Thrust per Engine & $\mathrm{lb}$ & 26,400 & 19,600 & & & & \\
\hline Start of Cruise SFC & 1/hr & 0.619 & 0.612 & & & & \\
\hline
\end{tabular}


Table 5 contains the top level aircraft parameters for the four optimized wing configurations. The next step was to move the wing to the high wing configuration. The wing weight decreased about 1,600 pounds, but the OEW increased slightly. More fuel is required to fly the design range, so the takeoff gross weight increased about 9,000 pounds. Top level wing design changes include a decrease in aspect ratio and a small decrease in wing area. The high wing also decreased the outboard sweep and moved the wing break location closer to the fuselage. The lowest takeoff gross weight high wing design had a similar OEW to the low wing, but the wing changes created more $\mathrm{C}_{\mathrm{D}}$ and decreased the L/D. The block fuel increased which resulted in a higher takeoff gross weight than the low wing.

Table 5: Minimum Takeoff Gross Weight Design Objective Results.

\begin{tabular}{|c|c|c|c|c|c|}
\hline & Units & $\begin{array}{l}\text { Low Wing } \\
\text { Cantilever }\end{array}$ & $\begin{array}{l}\text { High Wing } \\
\text { Cantilever }\end{array}$ & $\begin{array}{c}\text { Strut-Braced } \\
\text { Wing } \\
\end{array}$ & $\begin{array}{c}\text { Truss-Braced } \\
\text { Wing } \\
\end{array}$ \\
\hline \multicolumn{6}{|l|}{ Mission Parameters } \\
\hline TOGW & $\mathrm{lb}$ & 154,100 & 163,200 & 161,700 & 166,100 \\
\hline OEW & $\mathrm{lb}$ & 86,600 & 87,300 & 86,900 & 87,300 \\
\hline Wing Weight & $\mathrm{lb}$ & 19,500 & 17,800 & 17,500 & 16,300 \\
\hline Payload & $\mathrm{lb}$ & 37,760 & 37,760 & 37,760 & 37,760 \\
\hline Number of Passengers & & 160 & 160 & 160 & 160 \\
\hline Range & $\mathrm{nm}$ & 2,875 & 2,875 & 2,875 & 2,875 \\
\hline Total Fuel & $\mathrm{lb}$ & 29,800 & 38,100 & 37,100 & 41,100 \\
\hline Block Fuel & $\mathrm{lb}$ & 24,200 & 31,400 & 30,300 & 33,900 \\
\hline Economic Range & $\mathrm{nm}$ & 900 & 900 & 900 & 900 \\
\hline $\begin{array}{lll}\text { Economic } & \text { Mission } & \text { Blk } \\
\text { Fuel } & & \\
\end{array}$ & $\mathrm{lb}$ & 8,500 & 10,400 & 10,300 & 11,100 \\
\hline \multicolumn{6}{|l|}{ Aircraft Parameters } \\
\hline Wing Area & $\mathrm{ft}^{2}$ & 1,350 & 1,310 & 1,380 & 1,280 \\
\hline Wing Span & $\mathrm{ft}$ & 133 & 125 & 119 & 113 \\
\hline AR & & 13.2 & 11.9 & 10.2 & 10.0 \\
\hline Wing Loading, W/S & $\mathrm{lb} / \mathrm{ft}^{2}$ & 115 & 125 & 117 & 129 \\
\hline Cruise Mach & & 0.78 & 0.78 & 0.78 & 0.78 \\
\hline Start of Cruise L/D & & 25.0 & 19.5 & 20.4 & 18.2 \\
\hline Start of Cruise $\mathrm{C}_{\mathrm{L}}$ & & 0.53 & 0.54 & 0.54 & 0.55 \\
\hline Start of Cruise $C_{D}$ & & 0.0211 & 0.0277 & 0.0263 & 0.0301 \\
\hline Start of Cruise Altitude & $\mathrm{ft}$ & 35,000 & 33,800 & 35,000 & 33,300 \\
\hline Thrust per Engine & $\mathrm{lb}$ & 19,600 & 21,400 & 21,000 & 23,900 \\
\hline Start of Cruise SFC & $1 / \mathrm{hr}$ & 0.612 & 0.616 & 0.614 & 0.616 \\
\hline \multicolumn{6}{|l|}{ Constraints } \\
\hline Range & $\mathrm{nm}$ & 2,875 & 2,875 & 2,875 & 2,875 \\
\hline Approach Speed & kts & 126 & 133 & 133 & 133 \\
\hline Takeoff Field Length & $\mathrm{ft}$ & 9,140 & 9,750 & 9,380 & 9,310 \\
\hline Landing Field Length & $\mathrm{ft}$ & 7,210 & 7,800 & 7,910 & 7,800 \\
\hline Missed Approach & $\mathrm{lb}$ & 62 & 0 & 0 & 306 \\
\hline Second Segment Climb & $\mathrm{lb}$ & 4,080 & 4,510 & 4,200 & 5,650 \\
\hline
\end{tabular}

After the wing was moved to the high location, a strut was added. The wing weight decreased 300 pounds from the optimized configuration change and the OEW decreased about 400 pounds. Less fuel is required to fly the design range, so the takeoff gross weight also decreased about 500 pounds. Top level wing changes include a decrease in aspect ratio and an increase in wing area. The strut-braced wing also increased the inboard wing sweep, decreased the outboard wing sweep, and moved the wing break location farther from the fuselage. The lowest takeoff gross weight SBW design had a lower OEW to the high wing and the wing changes decreased $C_{D}$, but $L / D$ and $C_{L}$ slightly increased. The small decreases in the OEW and block fuel resulted in a lower takeoff gross weight than the high wing. The strut-braced wing has a slight advantage over the high wing configuration in terms of takeoff gross weight. 
One jury was added to the strut-braced wing to create the truss-braced wing. The wing weight decreased 1,200 pounds compared to the strut-braced wing. The OEW however increased about 400 pounds. The truss-braced wing block fuel increased and the takeoff gross weight consequently increased over 4,000 pounds. Top level wing changes include a decrease in aspect ratio and wing area. The thrust required increased. The truss-braced wing decreased the wing sweep to near zero, decreased the taper ratio, and moved the wing break location closer to the fuselage. The wing changes resulted in a lower $\mathrm{L} / \mathrm{D}$ and a higher drag coefficient.

\section{Conclusions}

This study focused on various wing designs to meet a transport aircraft mission of 2,875 nm with 160 passengers. The current state-of-the-art aircraft in this market are all low wing cantilever configurations. Trussbraced wing, strut-braced wing, high wing cantilever, and low wing cantilever aircraft have all been built and flown in some form. Current advances in technology and the recent increase in research of these wing configurations could enable the unconventional configurations to compete with the low wing cantilever for future designs in this vehicle class. No manufacturers have announced any new wing configuration designs to date. The results of this study support the low wing as the best design choice for current technology aircraft.

Takeoff gross weight is often used as a measurable quantity to indicate life cycle cost of an aircraft. The aircraft configuration with the lowest takeoff gross weight in this study was the low wing cantilever. The second lowest TOGW was the high wing cantilever, then the strut-braced wing, and lastly the truss-braced wing. One note that must be made is that although the design variables were constrained, the actual limits that an aircraft manufacturer would use are not known. Therefore, it is not assumed that the optimized aircraft found here are the best deisgn choices to go forward to the preliminary design stage. Rather, the goal of the optimization study was to be consistent to ensure that relative comparisons could be made.

The truss-braced wing aircraft had the highest TOGW and it may also be the most complex. The concept exists to reduce the wing weight and chord lengths. Exterior structural members are added to the wing including the strut and the jury. In general, an increase in parts leads to an increase in complexity and this could be the case for this configuration. The original intent of the TBW concept was to increase laminar flow which has been tested for many years, but is still believed to be a future technology. Therefore, some risk exists in obtaining and maintaining the benefits from laminar flow wings. The lighter and thinner wing will also increase the risk of flutter. This risk is currently being assessed by Boeing under the NASA SUGAR contract.

Throughout the duration of this study several noteworthy concerns arose. One concern was the design variable constraints. They play a big part in the geometry of the resulting aircraft, however their true limits are not known. Most of the constraints are set by manufacturing constraints which were not used in this study. The last concern is the optimization technique itself. The methodology used was consistent to allow comparrisons for this study among very different wing configurations. However, the analysis modules and architecture of the ModelCenter ${ }^{\circledR}$ model make the MDO tool cumbersome. Through the use of the optimizers, it was clear that errors or invalid results can easily occur especially with large ranges on the design variables. It is recommended that small ranges be used with some thought to manufacturing constraints.

Although it was difficult to set up this study, a somewhat surprising result was that the optimized truss-braced wing configurations had high takeoff gross weights and some of lowest aspect ratios while the low wing cantilever had the lowest takeoff gross weights and the highest aspect ratios. The wing weight of the truss-braced wing is lower than the low wing for the TOGW optimized aircraft. In fact, the wing weight decreased from the low to the high wing, from the high to the strut-braced wing, and again from the strut-braced to the truss-braced wing. One advantage that the truss-braced strut-braced wings have is that they can reduce wing weight in an effort to reduce the takeoff gross weight. The aspect ratio and L/D were expected to increase from the low wing to the truss-braced wing. This may have occurred due to the wing materials and could change if the wing was built of advanced composites or other lightweight materials. The L/D optimized truss-braced wing had an AR of 17.4 and an L/D of 24.6 with a TOGW of 217,200 pounds. The Hurel Dubois HD-31 had an aspect ratio in the 20's with a high L/D and did not use any advanced materials. This study leads to the conclusion that using a strut or truss structural wing system increases the takeoff gross weight.

It was not surprising that different design objectives resulted in different aircraft. The maximum lift-to-drag ratio design is not the minimum fuel burn design! This is because a larger/heavier aircraft is required to meet the mission requirements. Care should be taken in selecting design objectives for every aircraft design study. They do play an important role in the resulting aircraft's geometry. As the results of this study suggest, the truss-braced wing configuration may not provide advantages over the low wing cantilever for passenger aircraft that are designed for the 2,875 $\mathrm{nm}$ mission when optimizing for the lowest takeoff gross weight. However, advanced light weight 
materials might enable the truss-braced wing to be competitive. Boeing and NASA are working together to reduce some of the risk associated with this configuration so the true benefits can be quantified.

\section{Acknowledgments}

First and foremost I would like to thank God for blessing me with talent and a passion for aircraft design. Thank you to those who contributed: Mark Guynn, Craig Nickol, Andy Hahn, Bill Fredericks, Frank Gern (NASA Langley Research Center), Dr. Taewoo Nam (Georgia Tech), Dr. Joseph Schetz (Virginia Tech), and Christopher Droney (Boeing). This study was supported by Dr. Rubén Del Rosario under NASA's Fixed Wing project of the Fundamental Aeronautics Program.

\section{References}

${ }^{1}$ Warwick, G., "NASA's New Look at Braced Wings," Aviation Week and Space Technology Blog, [online blog], URL: http://www.aviationweek.com/Blogs.aspx?plckBlogId=Blog:a68cb417-3364-4fbf-a9dd-

4feda680ec9c\&plckPostId=Blog\%3Aa68cb417-3364-4fbf-a9dd-4feda680ec9cPost\%3Aa2976f0d-8632-490b-b58f-

0aed33b6a73d, [cited 1 May 2013].

2“French Air Oddities”, Popular Mechanics Magazine, Vol. 100, No. 6, Dec. 1953, pp. 115.

3“"Hurel Dubois Transports: Progress with the HD-31 and 32: The HD-45 Jet Project", Flight and Aircraft Engineer: Official Organ of the Royal Aero Club, Vol. 2288, No. 62, 28 Nov. 1952, pp. 676-677.

4،"Hurel-Dubois H.D. 32: An Appraisal of the Unorthodox yet Promising Type Ordered by Air France", Flight and Aircraft Engineer: Official Organ of the Royal Aero Club, Vol. 2369, No. 65, 18 Jun. 1954, pp. 793-796.

5“JOHAN VISSCHEDIJK COLLECTION: No. 8394. Hurel-Dubois HD.31 (F-BFKU c/n 01),” 1000AircraftPhotos.Com, [online database], URL: http://1000aircraftphotos.com/Contributions/Visschedijk/8394L-2.jpg, [cited 15 Nov. 2013].

${ }^{6}$ Pfenninger, W., "Laminar Flow Control Laminarization," AGARD Report 654, "Special Course on Concepts for Drag Reduction", 1977, Summarized from the report "Some thoughts on the design of large global range LFC transport airplanes," Jan., 1976.

${ }^{7}$ Ko, A., Grossman, B., and Mason, W. H., "The Role of Constraints in the MDO of a Cantilever and Strut-Braced Wing Transonic Commercial Transport Aircraft”, AIAA Paper 2000-01-5609, Oct. 2000.

${ }^{8}$ Sulaeman, E., Kapania, R. K. and Haftka, R. T., "Parametric Studies of Flutter Speed in a Strut-Braced Wing", AIAA Paper 2002-1487, 2002.

${ }^{9}$ Gern, F. H., Ko, A., Grossman, B., Haftka, R. T., Kapania R. K., and Mason, W. H., "Transport Weight Reduction through MDO: The Strut-Braced Wing Transonic Transport", AIAA Paper 2005-4667, Jun. 2005.

${ }^{10}$ Leifsson, L. T., Mason, W. H., Schetz, J. A. Haftka, R. T., and Grossman, B., "Multidisciplinary Design Optimization of Low-Airframe-Noise Transport Aircraft”, AIAA Paper 2006-230, Jan. 2006.

${ }^{11}$ Bhatia, M., Kapania, R. K., van Hoek, M. and Haftka, R. T. "Structural Design of a Truss-Braced Wing: Potential and Challenges," AIAA Paper 2009-2147, 2009.

${ }^{12}$ Morris, Gur O., Bhatia M., Mason W.H., Schetz J.A., Kapania R.K., and T. Nam "Development of framework for trussbraced wing conceptual MDO,” AIAA Paper 2010-2754, Apr. 2010.

${ }^{13}$ Bhatia, M., Kapania, R. K., Gur, O., Schetz, J. A., Mason, W. H. and Haftka, R. T., "Progress Towards Multidisciplinary Design Optimization of Truss-Braced Wing Aircraft with Flutter Constraint”, AIAA Paper 2010-9077, 2010.

${ }^{14}$ Seber, G., Ran, H., Schetz, J. A., and Mavris D. N., "Multidisciplinary optimization of Truss Braced Wing Aircraft with Upgraded Aerodynamic Analyses”, AIAA Paper 2011-3179, Jun. 2011.

${ }^{15}$ Mallik, W., Kapania R. K., and Schetz, J. A., "Multidisciplinary Design Optimization of Medium-Range Transonic TrussBraced Wing Aircraft with Flutter Constraint", AIAA Paper 2013-1454, Apr. 2013.

${ }^{16}$ Gundlach, J. F., Tetrault, P. A., Gern, F. H., Naghshineh-Pour, A. H., Ko, A., Schetz, J. A., Mason, W. H., Kapania R. K., Grossman, B. and Haftka, R. T., "Conceptual Design Studies of a Strut-Braced Wing Transonic Transport", Journal of Aircraft, Vol. 37, No. 6, Nov.-Dec. 2000, pp. 976-983.

${ }^{17}$ Gern, F. H., Ko, A., Sulaeman, E., Gundlach, J. F., Kapania R. K., and Haftka, R. T., "Multidisciplinary Design Optimization of a Transonic Commercial Transport with Strut-Braced Wing”, Journal of Aircraft, Vol. 38, No. 6, Nov.-Dec. 2001, pp. 1006-1014.

${ }^{18}$ Gur, O., Bhatia, M., Schetz, J. A., Mason, W. H., Kapania, R. K. and Mavris, D. N., "Design Optimization of a TrussBraced Wing Transonic Transport Aircraft", Journal of Aircraft, Vol. 47, No. 6, Nov. 2010, pp. 1907-1917.

${ }^{19}$ Gur, O., Schetz, J. A., Mason, W. H., "Aerodynamic Considerations in the Design of Truss Braced Wing Aircraft", Journal of Aircraft, Vol. 48, No. 3, 2011, pp. 919-939.

${ }^{20}$ Bhatia, M., Kapania, R. K. and Haftka, R. T., "Structural and Aeroelastic Characteristics of Truss Braced Wings: A Parametric Study”, Journal of Aircraft, Vol. 49, No. 1, Jan. 2012, pp. 302-310.

${ }^{21}$ Meadows, N. A., Schetz, J. A., Kapania, R. K., Bhatia, M. and Seber, G., "Multidisciplinary Design Optimization of a Medium Range Transonic Truss-Braced Wing Transport Aircraft", Journal of Aircraft, Vol. 49, No. 6, Nov. 2012, pp. 18441856.

${ }^{22}$ Grasmeyer, J. M., "Multidisciplinary Design Optimization of a Strut-Braced Wing Aircraft”, M.Sc. Dissertation, Aerospace and Ocean Engineering Dept., Virginia Polytechnic Institute and State Univ., 1998. 
${ }^{23}$ Naghshineh-Pour, A. H., "Structural Optimization and Design of a Strut-Braced Wing Aircraft", M.Sc. Dissertation, Aerospace and Ocean Engineering Dept., Virginia Polytechnic Institute and State Univ., 1998.

${ }^{24}$ Tétrault, P., "Numerical Prediction of the Interference Drag of a Streamlined Strut Intersecting a Surface in Transonic Flow", Ph.D. Dissertation, Aerospace and Ocean Engineering Dept., Virginia Polytechnic Institute and State Univ., 2000.

${ }^{25}$ Ko, A., "The Role of Constraints and Vehicle Concepts in Transport Design: A comparison of Cantilever and Strut-Braced Wing Airplane Concepts”, M.Sc. Dissertation, Aerospace and Ocean Engineering Dept., Virginia Polytechnic Institute and State Univ., 2000.

${ }^{26}$ Sulaeman, E., "Effect of Compressive Force on Aeroelastic Stability of a Strut-Braced Wing", Ph.D. Dissertation, Aerospace and Ocean Engineering Dept., Virginia Polytechnic Institute and State Univ., 2001.

${ }^{27}$ Liefsson, L. T., "Multidisciplinary Design Optimization of Low Noise Transport Aircraft", Ph.D. Dissertation, Aerospace and Ocean Engineering Dept., Virginia Polytechnic Institute and State Univ., 2005.

${ }^{28}$ Meadows, N., "Multidisciplinary Design Optimization of a Medium Range Transonic Truss-Braced Wing Transport Aircraft", M.Sc. Dissertation, Aerospace and Ocean Engineering Dept., Virginia Polytechnic Institute and State Univ., 2011.

${ }^{29}$ Morris, J. and Ashford, D., "Fuselage Configuration Studies," SAE Technical Paper 670370, 1967.

30"PHX ModelCenter | Desktop Trade Studies," Phoenix Integration, Inc. Website, [online database], URL: http://www.phoenix-int.com/software/phx-modelcenter.php, [cited 25 Nov. 2013]. 